Summer 2008

\title{
Toward a World Migratory Regime
}

\author{
Raffaele Marchetti \\ LUISS University, Rome
}

Follow this and additional works at: https://www.repository.law.indiana.edu/ijgls

Part of the Immigration Law Commons, and the International Trade Law Commons

\section{Recommended Citation}

Marchetti, Raffaele (2008) "Toward a World Migratory Regime," Indiana Journal of Global Legal Studies:

Vol. 15 : Iss. 2 , Article 2.

Available at: https://www.repository.law.indiana.edu/ijgls/vol15/iss2/2

This Article is brought to you for free and open access by the Law School Journals at Digital Repository @ Maurer Law. It has been accepted for inclusion in Indiana Journal of Global Legal Studies by an authorized editor of Digital Repository @ Maurer Law. For more information, please contact rvaughan@indiana.edu.

\section{$\Psi$}

JEROME HALL LAW LIBRARY

INDIANA UNIVERSITY

Maurer School of Law
Bloomington 


\title{
Toward a World Migratory Regime
}

\author{
RafFaEle Marchetti ${ }^{\circ}$
}

\begin{abstract}
Increasing transnationalism challenges the predominant statist treatment of migration and citizenship. Global, indeed cosmopolitan, citizenship offers an alternative to open border policies and global migratory management that focuses on the extent to which political agents are free to move and join different societies. Multilayered citizenship and multileveled political membership encourages a supranational institution dedicated to global deliberation. Such a migratory regulatory system and new admission criteria developed under the universal membership regime ensure the grant of civil, social, and political rights to all migrants.
\end{abstract}

\section{INTRODUCTION}

The man who finds his homeland sweet is still a tender beginner; the man for whom each country is as his native soil is already strong; but only the man for whom the whole world is as a foreign land is perfect.'

The traditional statist stance on migration, according to which the sovereign state retains an almost absolute discretion with regard to accepting foreigners into

* Laurea (Rome), Ph.D. (London). Lecturer in International Relations and coordinator, FP6 Strep Project SHUR, Human Rights in Conflicts: The Role of Civil Society (LUISS University, Rome). Previous versions of this article were presented at the International Relations Theory Workshop and the Political Theory Workshop (LSE, London), the Leverhulme Workshop, Global Ethics in the Context of Global Democracy and Globalization (University of Aberdeen), the 2nd World Public Forum Dialogue of Civilizations (Rhodes), and the First Global International Studies Conference-WISC (Bilgi University, Istanbul). Many thanks to all participants in those meetings. Special debt is acknowledged to D. A rchibugi, I. Charvet, C. Chwaszcza, D. Held, D. Kast, P. Kelly, F. Kratochwil, L. Schuster, O. Tribulato, and L.Ypi for their insightful comments.

1. Fred Dallmayr, Dialogue Among Civilizations: Some Exemplaky Voices 1 (2002).

Indiana Journal of Global Legal Studies Vol. 15 \#2 (Summer 2008)

CIndiana University School of Law 
its own territory, represents one of the clearest examples of international exclusion. Underpinning this discretion is a creed of the statist-communitarian paradigm that insists citizenship intrinsically refers to membership in a limited political organization-i.e., the state. According to this widespread position, the very expression "cosmopolitan citizenship" is an oxymoron insomuch as any attempt to expand the notion of citizenship beyond the limits of the community would necessarily result in self-contradiction. And yet, this statist creed is increasingly contested both in practice and theory by forms of transnationalism. At the practical level, more and more states recognize the possibility of multiple allegiances - i.e., multiple passports-and, in a different way, recent developments in international law chip away at state prerogatives as they show a tendency to grant increased legal relevance to universal human rights in areas such as those pertaining to social and civil rights. Similarly, at the normative level discretionary admittance policies have recently been challenged by two kinds of universalistic recommendations: open border policies and global migratory management. Together with the discredited and yet predominant statist view, these two counteralternatives delimit the normative discussion on migration.

In contrast to both statism and open borders, this article presents a proposal for a new reading of citizenship, and for its supranational institutional correlate in terms of migratory cosmopolitanism. Against state-centric logic, this article holds that while the concept of (single or multiple) nationality is inseparable from the notion of a sovereign state, the concept of citizenship is not, insofar as it can be unfolded and spread out over a number of political spheres. Consequently, no normative obstacles impede the expansion of the traditional notion of polis to the entire cosmos. Cosmo-political citizenship is, thus, understood to have significant meaning and value. This position, however, need not fall into a straightforward proposal for open borders. In opposition to such perspective, the argument presented here maintains that open border (non)arrangements should be equally refused in that they would violate the principle of impartiality. In overlooking the relative value of community self-determination and the possible risk of communal disruption, in fact, open borders arrangements do not take into appropriate consideration both original residents' and migrants' expectations.

An interpretation of cosmopolitan citizenship in terms of freedom of movement forms the core of this article. According to a consequentialist cosmopolitan principle of justice, in order to increase social welfare, freedom of movement must constitute a key component of individual freedom of choice that needs to be promoted within a multilayered scheme of political rights. Freedom of choice has to 
be inserted in a wider framework in which others' freedom of choice-as implemented through rights of residency and citizenship-has similar, prima facie claims of legitimacy. As a result, balancing different sets of entitlements through impartial institutional mechanisms remains a key political exercise for achieving legitimacy at any level of political action, including the global. Deploying a global, single principle of justice, such a consequentialist reading of politics thus generates a system that is internally differentiated and yet comprehensively consistent.

While the mainstream argument for global citizenship is primarily concerned with the capacity of political agents to influence, from their respective positions, those public decisions whose consequences extend beyond national borders, this article aims to study the other, less discussed, aspect of global citizenship which concerns not the scope of global public accountability but the extent to which political agents are free to move and join different societies. Accordingly, the primary object of concern here is individuals' capacity to modify their personal choice possibilities through changing their place of residency, which allows them to pursue control over the political system and over their own future. Once the principle of control over one's own life is endorsed, the issue of original residency becomes less significant for both aspects of global citizenship-i.e., transnational accountability and transnational movement. On this last account the treatment of migrants becomes a central test of the legitimacy of the political system.

In contrast to existing international law and national policies, migrants are recognized as cosmopolitan stakeholders entitled to rights that extend to different spheres of political action. ${ }^{2}$ According to the long-term emancipation project of cosmopolitanism, the right to free passage is considered a progressive entitlement of nondiscrimination which contributes to the maximization of individual choice possibilities, thus to his self-determination. For it to be established, the institution of an international organization specifically dedicated to the global deliberation on migration management is recommended, where the different stakeholders can present and politically weigh their claims, from an equal standing. Within the subsequent form of a world migratory regime, states would lose their absolute privilege of admission, and a more consensual method of allocating entrance per-

2. See Raffaele Marchetti, Global Democracy: For and Against: Ethical Theory, Institutional Design, and Social Struggles (2008); Raffaele Marchetti, Human Rights as Global Participatory Entitlements, in Between Cosmopolitan Ideals and State Sovereignty: Studies in Global Justice 159 (Ronald Tinnevelt \& Gert Verschragen eds., 2006); Raffaele Marchetti, Right to Universal Mobility: A Consequentialist Cosmopolitan Reading, 4 Ethics \& Econ. (2006), http:// ethics-economics.net/IMG/pdf/MARCHETTI.pdf. 
mission and international responsibility would be implemented that can eliminate some injustices of the present nation-led system.

This article starts by setting out the defining characteristics of migration and the political concept of citizenship, with a brief survey of current institutions and policies regarding migration. The core argument for the cosmopolitan interpretation of migration and citizenship is then introduced. Concluding recommendations for the creation of a supranational institutional framework of migratory cosmopolitanism are formulated thereafter.

\section{The Relation Between Migration and Citizenship}

Migration is, in this context, examined with reference to the political dimension of movement concerning the issues of admission into a foreign political society and citizenship. While citizenship generally is understood as the set of legal entitlements allowing for full community membership, conventionally three different subsets of citizenship rights can be distinguished according to their scope: civil, political, and socioeconomic rights. ${ }^{3}$ These entitlements, which are based on a fundamental principle of equality and reciprocity, are impartially guaranteed to every member of the community. Insofar as membership within the collective exercising self-governance is usually recognized as the minimal precondition of democratic life, the acquisition of this set of rights is considered crucial to effective participation in social and political life. ${ }^{4}$

There have been two major alternative principles governing the acquisition of citizenship: jus solii and jus sanguinis. While the first grants citizenship to everyone born within the territory of the country, the second considers blood relationship as the determining distinction. These principles have been inconsistently integrated with the practices of naturalization and together they form the basis of the traditional concept of allegiance, according to which loyalty is due to one's own country regardless of any other kind of secondary responsibilities extending beyond borders. In accordance with such due loyalty, the state has the prerogative

3. In recent years, there have been strong advocates for a further cultural component of citizenship, relying on the possibility of identification with a communitarian identity. Will Kymlicka, Immigration, Citizenship, Multiculturalism: Exploring the Links, 74 PoL. Q. 195, 195-208 (2003). According to this position, the concept of nationality remains strictly related to that of citizenship. See generally David Miller, ON Nationality (1995).

4. Gerard Delanty, Citizenship in a Global Age: Society, Culture, Politics 7-35 (Tim May ed., 2000); Will Kymlicka \& Norman Wayne, A Return of the Citizen: A Survey of Recent Work on Citizenship Theory, 104 Eтнісs 352, 352-81 (1994). 
to limit access to citizenship. In order to grasp the critical meaning of the current proposal, it is fundamental to note that current customary international law grants to the state an absolute right to refuse admission. While sovereignty is threatened in other respects, legislating the admission of immigrants is one instance in which state prerogatives are still intact. Provided no relevant conventions or humanitarian measures are applicable, ${ }^{5}$ the refusal to admit an alien is never an illicit act. However, if an alien already resides in the national territory, the right of the state to remove him or her is partially limited; accordingly, there is no absolute right to expulsion. ${ }^{6}$ The only agents toward whom the state has an international duty of admission are its own citizens.

The statist stance is, however, increasingly under pressure, from both a normative point of view for its inconsistency with fundamental principles of impartiality, and as a matter of fact, as increasing numbers of states recognize the possibility of double or even multiple citizenship. ${ }^{7}$ The same point of tension can also be exposed observing the public interpretation of migratory issues. Migration is commonly included in the list of the global issues, and yet is almost exclusively

5. U.N. Charter; Universal Declaration of Human Rights, G.A. Res. 217A (III), U.N. GAOR, 3rd Sess., lst plen. mtg., U.N. Doc. A/810 (Dec. 10, 1948); Convention Relating to the Status of Refugees, U.N. Conference on Plenipotentiaries on the Status of Refugees and Stateless Persons (July 28, 1951); Int'l Covenant on Econ., Social and Cultural Rights and the Int'l Covenant on Civil and Pol. Rights, G.A. Res. 2200A (XXI), U.N. GAOR, 21st Sess., U.N. Doc. A/6316 (Dec. 16, 1966); Int'l Convention on the Elimination of All Forms of Racial Discrimination, G.A. Res. 2106 (XX), 20th Sess., U.N. Doc. A/6014 (Dec. 21, 1965); Convention Against Torture and Other Cruel, Inhuman or Degrading Treatment or Punishment, G.A. Res. 29/46, U.N. GAOR, 39th Sess., U.N. Doc. A/39/51 (Dec. 10, 1984); Int'l Convention on the Protection of the Rights of All Migrant Workers and Members of Their Families, G.A. Res. 45/158, U.N. GAOR, 45th Sess., U.N. Doc. A/45/49 (Dec. 18, 1990). All impose a number of limits on state sovereignty, according to the principle of non-discrimination. So do other recommendations and non-binding documents from diverse international organizations related to the issue of migration such as the UNHCR, ILO, IOM, and WTO. In this regard, the EU system constitutes a sui generis institution, for while granting complete freedom of movement to its members, it is increasingly exclusionary toward non-members. It is important to remark, however, that these international agreements represent exceptional and external constraints on the original state entitlement to administer membership rights. In particular, they require the equal treatment of the aliens once they are in the national territory. Yet, only very rarely do they comment on the admission itself, except in the case of the reunion of minors to parents and refugees.

6. Guy S. Goodwin-Gill, International. Law and the Monement of Persons Between States 136 (1978); Bruno Nascimbene, Il Trattamento Dello Straniero Nel. Diritto InterNazionale ed Europeo 221-78 (1984).

7. Saskia Sassen, Beyond Sovereignty: De-facto Transnationalism in Immigration Policy, I Eur. J. Migration L. 177-98 (1999). 
managed by national or regional policies. ${ }^{8}$ This disconnect reveals a fundamental normative contradiction between claims that are universal to all humans and the communitarian entitlements upheld by mainstream political philosophy as well as national and international laws. The most blatant example of this contradictory logic at work is Article 13 of the Universal Declaration of Human Rights concerning the right to leave (but not to enter into) any country. ${ }^{9}$

In particular, the tension between universal claims and national prerogatives can be observed in the different juridical status given to aliens once they are admitted in a foreign territory. Although such juridical status remains diverse from state to state, it is possible to identify general trends in the treatment of migrants once they are admitted. While migrants are usually entitled to civil and socioeconomic rights, their access to political rights is still very much constrained, as opposed to the domestic Marshallian trend..$^{10}$ Differences in treatment depend on the different recognition migrants receive in each sector of public life. In civil and social terms, they are recognized as persons due to a progressive recognition of a sort of post-national personhood anchored to human rights principles. Politically, on the other hand, they remain noncitizens or denizens, for the identity-based character of political nationality has been exacerbated and "incorporation into a system of membership rights does not inevitably require [anymore] incorporation into the national collectivity." state (citizens) and rightful residents without all the rights has consequently been shaped in most of the receiving countries over the last decades. ${ }^{12}$

8. The first international attempt to deal with this issue took place only in 1998 with the U.N. Technical Symposium on International Migration and Development. Far from being an intergovernmental conference, this meeting represents a first feeble recognition of the world relevance of migration. Only recently, U.N. Secretary General Kofi Annan called for the creation of a U.N. Migration Agency (Nov. 24, 2003), but the effective implementation of such a proposal still seems far in the future. As a matter of fact, the latest Report of the Global Commission on International Migration (October 2005) advocated only an Inter-agency Global Migration Facility. Excluding the illegal international trafficking of people, national policies remain therefore the most relevant current mode of management of migratory flows.

9. Universal Declaration of Human Rights, G.A. Res. 217A, at art. 13, U.N. GAOR, 3d Sess., 1st plen. mtg., U.N. Doc. A/810 (Dec. 12, 1948).

10. Virginie Guiraudon, The Marshallian Triptych Reordered: The Role of Courts and Bureaucracies in Furthering Migrants' Social Rights, in Immigration and Welfare: Challenging the Borders of the Welfare State 72-89 (Michael Bommes \& Andrew Geddes eds., 2000).

11. Yasemin Soysal, Limits of Citizenship: Migrants and Post-National Membership in EuRope 3 (1994).

12. Alessandro Dal lago, Non-Persone. L'esclusione Dei Migranti in una Società Globale (1999); Bhikhu Parekh, Three Theories of Immigration, in Strangers and Citizens: A Positive Approach to Migrants and Rffugees 91, 91-110 (Sarah Spencer ed., 1994). 
One way of reinterpreting the tension between universal and national claims concerning the issue of immigration consists in progressively drawing limits to state sovereignty according to superior international laws. Usually this interpretation implies considering migrants in the negative aspect as aliens, or noncitizens and non-subjects, the state being accepted as the only agent entitled to confer such privileged status. This approach typically corresponds to the image of concentric circles, according to which the starting reference is constituted by the group (or even the family) and from there progressive enlargements are envisaged. In diametrical opposition to this exclusionary mechanism, this article advocates an approach that is cosmopolitan and all-inclusive from the beginning. Migrants are not noncitizens with only narrowly circumscribed rights, but cosmopolitan citizens entitled to the same rights that "permanent residents" have to control the decision-making processes worldwide which extend to different spheres of political action. In accordance with a new concept of universal membership based on a deterritorialized notion of a person's rights, this article develops an argument for a consistent global democratic regime able to grant not only civil and social, but also political rights to migrants, through a legitimate migratory regulatory system.

\section{Cosmopolitan Migratory Citizenship}

Two principal dilemmas concerning the notion of citizenship challenge any normative political theory that aims to deal with the theme of migration: (1) if and how to admit new would-be migrants (admission policy), and (2) how to deal with the received migrants (domestic treatment). ${ }^{13}$ Despite some recent attempts to consider migration from a wider perspective, a receiver's point of view still dominates in the normative literature on migration. ${ }^{14}$ By opting for a different vantage point beyond admission and treatment issues, this article deals with migration within a larger conceptual framework that also includes a third crucial element: the institution of multilevel citizenship as inherently anchored to global participatory entitlements.

With regards to the political reading of migration, the starting point of the cosmopolitanism argument on the movement of people stems from two different

13. Citizenship and Exclusion 1-11 (Veit-Michael Bader ed., 1997). See generally Justice in Immigration (Warren A. Schwartz ed., 1995).

14. For a critical survey, see Jonathan Seglow, The Ethics of Immigration, 3 Pol. Stud. Rev. 317-34 (2005). 
observations: one descriptive and one prescriptive. In factual terms, migration is considered principally and inevitably a global issue in that it refers to social phenomena primarily concerning the world level of political action and producing international effects. ${ }^{15}$ Historical patterns of migration have been fundamentally altered by the global transformations of recent decades. Even if borders were closed today, there would still be a continuous flow, both legal and illegal, due to a number of factors, including international and national norms of family reunion and political asylum. Even in an ideal world, the political question concerning the admission of aliens would persist, since even if poverty and violence were eliminated as causes of dislocation, there would still be personal motivations such as the desire to live in another society and lifestyle issues that would work as powerful engines of migration.

In normative terms, cosmopolitanism affirms that the scope of justice should be universal as no discrimination is justified when considering the ultimate rights of every citizen to control his destiny and to equal individual self-determination. In this vein, individual freedom of choice and the subsequent political entitlements to take part in the public decisionmaking process at all political levels form the normative core of the cosmopolitan criteria to assess international affairs. Underpinning this is the fundamental ethical postulate regarding impartiality that demands the extension of the application of the norm of individual nondiscrimination to the global level. ${ }^{16}$ In fact, in order to preserve his individual autonomy via freedom of choice, the agent needs to extend his political entitlement to the totality of the sphere of political action. This extended interpretation of political agency is particularly significant in those transborder cases, such as that of transnational migration, where traditional state-centric conceptions of citizenship demonstrate an increasing inappropriateness, both moral and political. In order to

15. This is radically different from Rawls's point of view, according to which in a realist utopia of liberal and decent states, the issue of migration would fall outside the scope of political concern. See John Rawls, The Idea of Public Reason Revisited (1997), reprinted in The Law of Peoples 8-9, 38-39 (1999); see also Patrick O'Neil, Rawls, the Right to Emigration, and the Mute Promise of the Original Position, 20 S.J. PHIL. 489 (1982). It must be noted that this is in contrast to Rawls's take at the domestic level, where the right to movement is included in the Rawlsian fundamental list of primary goods. See John Rawls, Social Unity and Primary Goods, in Utilitarianism and Beyond 159 (Amartya Sen \& Bernard Williams eds., 1982).

16. See Robert Goodin, If People Were Money..., in Frae Movement: Ethical Issues in the Transnational Migration of People and of Money 6 (Brian Barry \& Robert E. Goodin eds., 1992): Peter Singer \& Renata Singer, The Ethics of Refugees Policy, in Open borders? Closed Societies?: The Ethical and Political Issues 111 (Mark Gibney ed., 1988). 
comply with the requirements of global justice, such extension needs to be balanced, from an equal standing, with others' political entitlements.

These recognitions lead to the disputation of the mainstream framework according to which migration is considered only a national issue, because preference is given to residents' claims. Both nationalistic and globalist scholars commonly adopt part of the receiving country's perspective, inasmuch as admission to a country is considered the crux of the entire issue. ${ }^{17}$ According to cosmopolitanism, this move constitutes a prejudicial limitation of the original question. Since migrants have unequal standing, the question inevitably delivers a distorted and biased answer. As an alternative to this, a radical repositioning of the receiving countries is developed and an equalizing balance is struck between migrants and residents. The state-centric paradigm of national membership is rejected in favor of a global political principle of residency. And multilevel citizenship offers a unique chance for the social and political development of the theory and practice of democracy according to cosmopolitan principles.

Where this revolution of perspective occurs, there are two results: 1) the conferral of the equal status of cosmopolitan citizenship to migrants and "receiver" citizens concerning individual choice, and 2) the granting of the right to free passage concerning the movement of people. A cosmopolitan citizenship characterized by these entitlements becomes de facto a crucial institutional factor for individuals to increase, or even to implement, their autonomy among differing life options and their capability to govern the social-political domain by changing their places of residence. Much as at the domestic level the right to movement over the national territory has proved crucial in the self-realization of one's personal projects and political participation, ${ }^{18}$ an equivalent international right would be

17. Among nationalistic scholars, see Peter C. Meilaender, Toward a Theory of lmmigration (2001); David Miller, Citizenship and National Identity (2000); David Miller, Immigration: The Case for Limits, in Contemporary Debates in Applied Ethics (Andrew I. Cohen \& Christopher H. Wellman eds., 2003); Michael Walzer, The Distribution of Membership, in Boundaries: National Identity and its Limits (Peter G. Brown \& Henry Shue eds., 1981). Among globalist scholars, see Joseph H. Carens, Membership and Morality: Admission to Citizenship in Liberal Democratic States, in Immigration and the Politics of Citızenship 31 (William Rogers Brubaker ed., 1989); Citizenship and Exclusion, supra note 13; Robert Goodin, Reflective Democracy 202-04 (2003); Joseph H. Carens, Aliens and Citizens: The Case for Open Borders, 49 Rev. PoL. 251 (1987) [hereinafter Aliens and Citizens]; Seglow, supra note 14.

18. By contrast, it is instructive to look at all those national situations in which movement is restricted by legal or economic impediments: for example, the prohibition of the free movement of nationals in Italy during the period of fascist rule; or the poverty that prevents people in developing countries from travelling to another part of their own country. 
equally beneficial to the well-being of the individual in terms of choice opportunities and political control of one's own life..$^{19}$

Freedom of movement remains a necessary requirement for the implementation of political participation insofar as only by having such an entitlement can an individual join a group (possibly different from the individual's own original one) where the individual's opinion can be aggregated with other similar views, thus creating a substantial political voice able to influence public life according to the individual's own value set. This argument resembles that of a political party's pluralism within a voluntaristic model of politics. As much as the possibility of a plurality of political parties should be guaranteed in order to offer the individual the possibility to join the party that is most consistent with his views, so also the freedom to join a group or country where his personal views (political, social, and economical) sit comfortably should be guaranteed. Hence, the recognition of the right to free passage represents a legitimate political objective to be taken into consideration when shaping a multilayered political structure, insofar as it ultimately fosters the individual freedom of self-determination. ${ }^{20}$

Nonetheless, for this to satisfy the global democratic requirements concerning multilevel dimensionality, an impartial weighting mechanism between the claims of migrants and those of local citizens has to be simultaneously envisaged. Having argued for a universal right to movement, it is necessary to reiterate that such a right has to be inserted into a wider institutional political framework in which other kinds of rights also have legitimate claims. While migrants and residents are equal on the basis of a fundamental right to the protection of freedom of choice, they nonetheless differ in that the social value ${ }^{21}$ of their relative institutional entitlements concerning national citizenship can become unbalanced. This case is similar in many respects to the familiar situation of welfare state provision, in which one person's set of secondary rights conflicts with the secondary entitlements of others, despite both counterparts having fundamentally equal claims to

19. Roger Nett, The Civil Rights We Ave Not Ready For: The Right of Free Movement on the Face of the Earth, 81 Eruics 212,225-26 (1971).

20. Beyond the increase in individual freedom of choice, international movement would also create efficiency gains in a neo-classical sense, inasmuch as it would optimize resource allocation and so maximize economic welfare for the world as a whole. See Deepak Nayyar, Cross-Border Movements of People, in Governing Globalization 144, 162-65 (Deepak Nayyar ed., 2002); World Bank, Global Economic Prospects 2006: Economic Implications of Remittances and Migration 25-50 (2005).

21. Assessed on the basis of the sociopolitical performance of the given institution in terms of promoting world well-being. 
well-being, i.e., welfare provision from the state. In cases like this, some sort of impartial comparative assessment made by a public, all-inclusive institution is needed in order to solve the controversy. While institutional suggestions for the case of a world migratory regime will be provided in the next sections, here it is important to offer more details on the reasoning underpinning them.

Within the scheme of cosmopolitanism, national citizenship, as an institution of the state level of political action, maintains a certain degree of legitimacy according to a universal, indirect, and impartial division of moral labor. According to this division, different associative ties are recognized as prima facie valid sources of well-being, but in order to depart from such provisional status and gain definitive legitimacy, they need to be consistently embedded into a wider, global institutional framework. In this specific case, they need to pass through a comparative assessment against the migrants' conflicting entitlements. In this vein, the institution of national primary citizenship will only be warranted to the extent that its long-term social performance impartially contributes to the maximization of the individual freedom of choice, and therefore consistently meets the demands of the democratic institution of cosmopolitan citizenship.

Such comparative assessment between different citizenship-related entitlements is based on the expected capacity of each set of rights to contribute to the promotion of the individual freedom of choice via political participation. Such comparative assessment can only be carried out and agreed upon in an adequate institutional framework in which all counterparts have a fundamentally equal voice. Before introducing such a global institutional device, it is, however, necessary to offer a number of further considerations on the debated policy alternatives.

\section{Cosmopolitan Migratory Policy: Neither Statism nor Open Borders}

A number of policy consequences pertaining to the status of the citizen on the vertical and horizontal dimensions of transnational politics are generated by the rebalancing of the notion of citizenship according to an impartial, global standard of membership claims. By definition, the multilayered notion of cosmopolitan citizenship entails political membership at different levels. While state membership would still remain inevitably subject to some constraints (e.g., not all can be citizens of country $\mathrm{X}$ ), second order, global citizenship is characterized by all-inclusiveness (e.g., all can be world citizens). In this way, cosmopolitanism grants to individuals 
civil, social, and political rights in more than one country, and the complete parity of rights related to residency between local people and migrants. ${ }^{22}$

Accordingly, the state-centric point of view should be rejected for at least two reasons, which in different ways concern the principle of nondiscrimination. First, in conceding an almost absolute privilege to original residents, state-centric policies do not recognize the superveniency of the principle of impartial consideration of each individual's right to equal choice opportunity. Second, the nationalist orientation should be rejected for the way it intentionally discriminates among would-be migrants, admitting only those who satisfy entry requirements shaped on the needs of the receiving countries. In fact, it is very often the case that current policies of admission, which are mostly based on nationalist principles, filter the in-flow of would-be migrants in accordance with their potential to contribute to the domestic economy, leaving the remaining vast majority of would-be migrants unjustly excluded, without the right to appeal. When the nationalist stance is delegitimized, citizenship can be interpreted as the last bastion of privilege related to legal status and as an obstacle which resoundingly fails to meet the general obligation of nondiscrimination. Migrants can then be considered as the next informal political agents to acquire full political status. ${ }^{23}$

The rejection of the nationalistic position does not imply, however, the immediate acceptance of open borders because this policy could be self-defeating. Open borders policy has recently been restated with incisive arguments from both political scientists and economists, and it is likely to play a significant role in future public discussion on migration. ${ }^{24}$ From the present perspective, nonetheless,

22. April Carter, The Political Theory of Global Citizenship 109 (2001); Robert Goodin, Inclusion and Exclusion, 37 Eur. J. Soc. 343, 350 (1996).

23. Within this framework, the right to free passage is considered as a widening entitlement, part of a long-term emancipation project. From aristocrats to rich people, it is possible to trace a slow process of extension toward a universal right in practice, which brings into question the legitimacy of reserving the possibility of choice for the well-off and imposing the opposite limitation on the worst-off. Citizenship is here, in fact, taken as one, perhaps the only, privilege of status still firmly associated with the socio-economical division of people. Robert Goodin, Commentary: The Political Realism of Free Movement, in Free Movement: Ethical Issues in the Transnational Migration of People and of Money 248, 256-60 (Brian M. Barry \& Robert E. Goodin eds., 1992); Carens, Aliens and Citizens, supra note 17, at 268; Luigi Fer rajoli, I Diritti Fondamentali Nella Teoria del Diritto, 1 Teoria Politica 49 (1999).

24. For open borders arguments, see Teresa Hayter, Open Borders: The Case Against Immigration Controls 149-72 (2000); Satvinder Singh Juss, International Migration and Global Justice 3 (2006); Chandran Kukathas, The Case for Open Immigration, in Contemporary Debates in Applied Erhics 207 (Andrew I. Cohen \& Christopher Heath Wellman eds., 2005); Catherine Wihtol de Wenden, Faut-il Ouvrir les Frontières? (1999); Carens, Aliens and 
such a radical alternative should be refused for a number of distinct reasons related to the impartial dealing with both migrants and receiving populations. These reasons, however, are hypothetical because they regard possible - but not empirically provable-scenarios associated with the sudden fall of borders. Despite their non-provability, they cannot, however, be easily dismissed or worse, ignored, because they draw a significant non-ideal situation that normative reasoning needs to take into account. Concerning migrants, from the cosmopolitan point of view here endorsed, the policy of completely open borders here and now could be self-defeating, insofar as it could subvert the expectations of would-be migrants. The motivations of the would-be migrants to move include the possibility of reaching a specific country with its distinctive cultural, social, and economic context. ${ }^{25}$ However, an unrestrained and possibly sudden inflow of foreign people could bring about a radical reshaping of its fundamental characteristics, thus disappointing the original objectives of the migrants themselves.

As for local residents, a similar line of argument applies, and their expectations should also be taken into account with equal weight. At the moment, it is plausible to assert that most citizens of the porential receiving countries are not willing to accept such a universalistic policy, nor are their politicians. Were borders suddenly and completely open, a possible result could be a substantial reshaping of social identity and of the entire state structure, with potentially huge social costs in terms of well-being expectation. In this respect, the communitarian stance is partially right in claiming the importance of social identity and institutional traditions. ${ }^{26}$ While often underestimating the importance of the modes of incorporation of migrants in the sociopolitical context, ${ }^{27}$ such claims still hold a certain degree of validity (to be weighed against migrants' claims), for they recognize the residents' prima facie right to sustain their mode of life. ${ }^{28}$ Assuming such a right, a reasonable way forward consists in rethinking social evolution as the gradual renegotiation of political identity through a longer term process of aliens' admis-

Citizens, supra note 17, at 270-71; Liza Schuster, The Ethical Arguments for and Practical Implications of Recognising a Universal Right to Free Movement (2007) (unpublished manuscript, on file with author).

25. Russell Hardin, Migration and Community, 36 J. Soc. PhIL. 273 (2005); Samuel Scheffler, Immigration and the Significance of Culture, 35 Phil. \& Pub. Aff. 93 (2007).

26. David Miller, Immigrants, Nations, and Citizenship, J. PoL. PHIL. (2008), http://www.blackwellsynergy.com/doi/pdf/10.111//j.1467-9760.2007.00295.x.

27. Aristide R. Zolberg, Modes of Incorporation: Toward a Comparative Framework, in CitizenSHIP AND ExcLusion, supra note 13, at 139.

28. Bruce A. Ackerman, Social Justice in the Liberal State 95 (1980); Stephen R. Perry, Immigration, Justice, and Culture, in Justice is I mmigration 94, 95 (Warren F. Schwartz ed., 1995). 
sion. Hence, in opposition to an immediate open border policy, the strategy of reform by degrees seems the most appropriate.

Since an open border policy is not viable in the near future and yet the right to movement is universal in principle, the subsequent problem becomes how to distribute a scarce good (i.e., the right of residency in any state) equally, and so avoid the dramatic situation of the unjust sacrifice of the few. The constraints, which drawing on Humean terminology, I call the "circumstances of migratory justice," consist of the fact that many want to enjoy the relevant good (i.e., right of residency), and yet such a good is not infinite at the national level. This situation is further aggravated by the current "win-or-lose all" process that daily haunts the lives of so many migrants. Migrants refused at the border lose everything, while those who make it through (by chance or illicit means) win the lottery. Those migrants refused (who may well have greater ethical grounds for wanting admittance) are excluded by a jungle system, where physical force and social power very often decide the result, without any moral constraints. The sacrifice of a few migrants (but actually many lives) represents the tragic cost of sustaining such an unjust system-a cost which includes that of the other would-be migrants who remain at home, the legal migrants who have already been accepted, and the local population.

The response of cosmopolitanism to the arbitrariness of the present mechanisms for entering consists in a moralized and impartial treatment of the distribution of the permits of residency based on a universal right to movement embedded in an impartial global weighting mechanism. According to this cosmopolitical interpretation of citizenship and the notion of "regulated openness" or "fairly open borders," consists in the recognition that the right of residency and the related citizenship rights too must be reconsidered as impartially dividable over time and on different levels of political action. Universal availability of this good (i.e., the right of residency) is only possible through its division into temporally distributed parts. Consequently, temporally limited permissions of free movement and residency become the goods of this new migratory policy-goods widely available and complemented by limited extensions concerning the right to settlement and definitive change of primary state citizenship. Hence, a system of fair circulatory migration would result from temporary limited admissions.

29. Veit-Michael Bader, Fairly Open Borders, in Cirizenship and Exclusion, supra note 13, at 28; Bimal Ghosh, Toward a New International Regime for Orderly Movements of People, in Managing Migration. Time for a New International Regime? 6, 25 (Bimal Ghosh ed., 2000); Veit-Michael Bader, The Ethics of Immigration, 12 Constellations 331, 353-54 (2005). 
Having outlined this new interpretation of the notion of migration and citizenship, it is necessary to concentrate on its political-institutional consequences. So far, it has only been shown that citizenship should be reconceptualized in terms of global justice. Consistency demands that this first move now be followed by the identification of the global political means through which to obtain the maximization of the individual choice possibility. The following section is dedicated to showing how both a fair allocation of entrance permissions and an impartial distribution of burdens among international agents might be achieved through appropriate political institutions. As argued, since the issue at stake is global in kind, an adequate response must be equally global. In this regard, the establishment of an institutional framework of migratory cosmopolitanism forms a crucial component of the present proposal.

\section{Institutions of Migratory Cosmopolitanism: Toward a World Migratory Regime}

The previous sections have disputed the traditional understanding of the migratory phenomenon as a purely domestic political issue consisting, in the ultimate analysis, of a sheer problem of admission, and have subsequently recognized the necessity to create a legal-political structure able to manage and implement the "good" at stake, i.e., the right of residency. Since the agency entailed in the movement of people refers primarily to the global level of political action, the principles of justice to apply in this case have to be consistently calibrated as world responsibilities. ${ }^{30}$ The state should no longer be the only actor who decides, according to its own principle of justice, whether to admit the alien or not. If this were so, it would simply be a matter of designing a political mechanism for national efficiency. But the case is different and, more importantly, concerns the issue of assigning moral responsibility, i.e., making every agent accountable in each political sphere. In response to this, the suggestions envisaged for a future development of a regulatory framework consist of a set of institutional tools, composed of two main parts: an international convention and an international agency.

An international convention should be established in order to recognize migration as a global phenomenon. The convention should formulate a code of con-

30. Franck Düvell \& Bill Jordan, Migration: Boundaries of Equality and Justice (2003); Ghosh, supra note 29, at 25; Arthur C. Helton, Unpleasant Surprises Await: New Forms of International Cooperation Will Be Needed to Address the Myriad Problems That Will Arise When Vast Numbers of Humans Migrate, Bull. Aтом. Sci., Nov./Dec., 2002 at 94, 100. 
duct to be implemented through a two-tier mechanism at the domestic and global level. An example to have in mind is the United Nations Geneva Refugee Convention and its Protocol, which provide a similar framework for the specific case of refugees. ${ }^{31}$ As a complement to this convention, a World Migration Agency (possibly under the umbrella of a reformed United Nations, as suggested by Kofi Annan ${ }^{32}$ ) should also be created..$^{33}$ This would provide the appropriate place for negotiations and the appropriate force for implementation of the decisions concerning migratory fluxes. This new agency should be characterized by all-inclusiveness, for it should provide the forum where conflicting claims about the global issue of migration can be publicly discussed and weighed by all stakeholders on an equal standing. Hence, while the mode of deliberation should be based on a procedurally negotiated discussion, its competence should be supranational, thereby entailing the authority to override national decisions.

This new system of migratory cosmopolitanism would enhance the legitimacy, efficacy, and accountability of the decisions taken at the supranational level, and at the same time decrease the degree of widespread social criticism against the current situation. All involved agents would have the opportunity to express their point of view and to influence the decisionmaking process through appropriate political mechanisms. The creation of this new agency, to work in collaboration with several other institutional actors such as governmental and non-governmental organizations, remains, therefore, a crucial step toward the institutionalization of a legitimate global migratory regime.

Rules of nondiscrimination, such as universality of admission through temporariness, equality of treatment between locals and foreigners, and the most favored nation (MFN) clause, are the most appropriate candidate norms for this new regulatory framework. They would place a prima facie duty on the receiving countries to admit impartially without discriminating among sending countries. When a country did not exhaust its quota, then a mechanism for redistributing its

31. Convention Relating to the Status of Refugees, opened for signature July 28, 1951, 189 U.N.T.S. 150 , available at http://www.unhchr.ch/html/meu3/b/o_c_ref.htm.

32. Annan called for a dialogue on this hypothesis in 2003, which later generated The Report of the Global Commission on International Migration. Global Commission on International Migration, Migration in an Interconnected World: New Directions for Action (2005). See also The Secretary-General, Report of the Secretary-General on International Migration and Development, delivered to the General Assembly, U.N. Doc. A/60/871 (May 18, 2006).

33. See Ghosh, supra note 29; Rey Koslowski, Possible Steps Towards an International Regime for Mobility and Security, 8 Global Migration (2004), http://www.gcim.org/gmp/Global\% 20Migration\%20Perspectives\%20No\%208.pdf. 
remaining options to other sending countries should be activated. Moreover, a system of burden and benefit-sharing through national quotas should also be agreed upon to set the quantitative criteria for receiving countries. In contrast to national policies based on morally arbitrary and disproportionate distribution, each country should admit its fair share of migrants regardless of the orher countries' compliance with the organization's decisions. The amount of migratory load should then be decided by the supranational organization through an impartial and inclusive procedure of global deliberation.

\section{Conclusion}

Through the adoption of a radical change in political perspective that reinterprets migration and citizenship as global issues, the ultimate exclusionary arbitrariness of the admission criteria of state migratory policies and the resulting loss of any potential increase in individual choice opportunity have come into view. To the original contention that state migratory policies are morally unaccountable, this article has suggested a cosmopolitan, all-inclusive answer. The core of its cosmopolitan argument resides in a particular interpretation of the idea of a universal right to free passage that takes into account the "circumstances of migratory justice." From this, a number of political recommendations follow which are given substance in the proposal of new admission criteria and of a new system of migratory cosmopolitanism-the latter entailing the adoption of a convention on migrants and the establishment of a supranational cooperative agency to manage migratory flux.

Only through such a pluri-level political system can the possibility of individual choice receive an impartial hearing, in that multilevel citizenship is responsive to differing degrees of responsibility and relative power at all levels of political decision-making, including the global sphere. These are the appropriate political arrangements required by a cosmopolitan theory of global justice in the case of citizenship and migration. However, were the circumstances to differ in the future, political norms should be revised accordingly. Flexibility and reformism need to be combined with an awareness that moral law can only require a partial revision of social reality and that it is only reasonable to assume that international institutions will be fairer than national ones, much as national institutions are usually considered fairer than uncoordinated individual actions. 

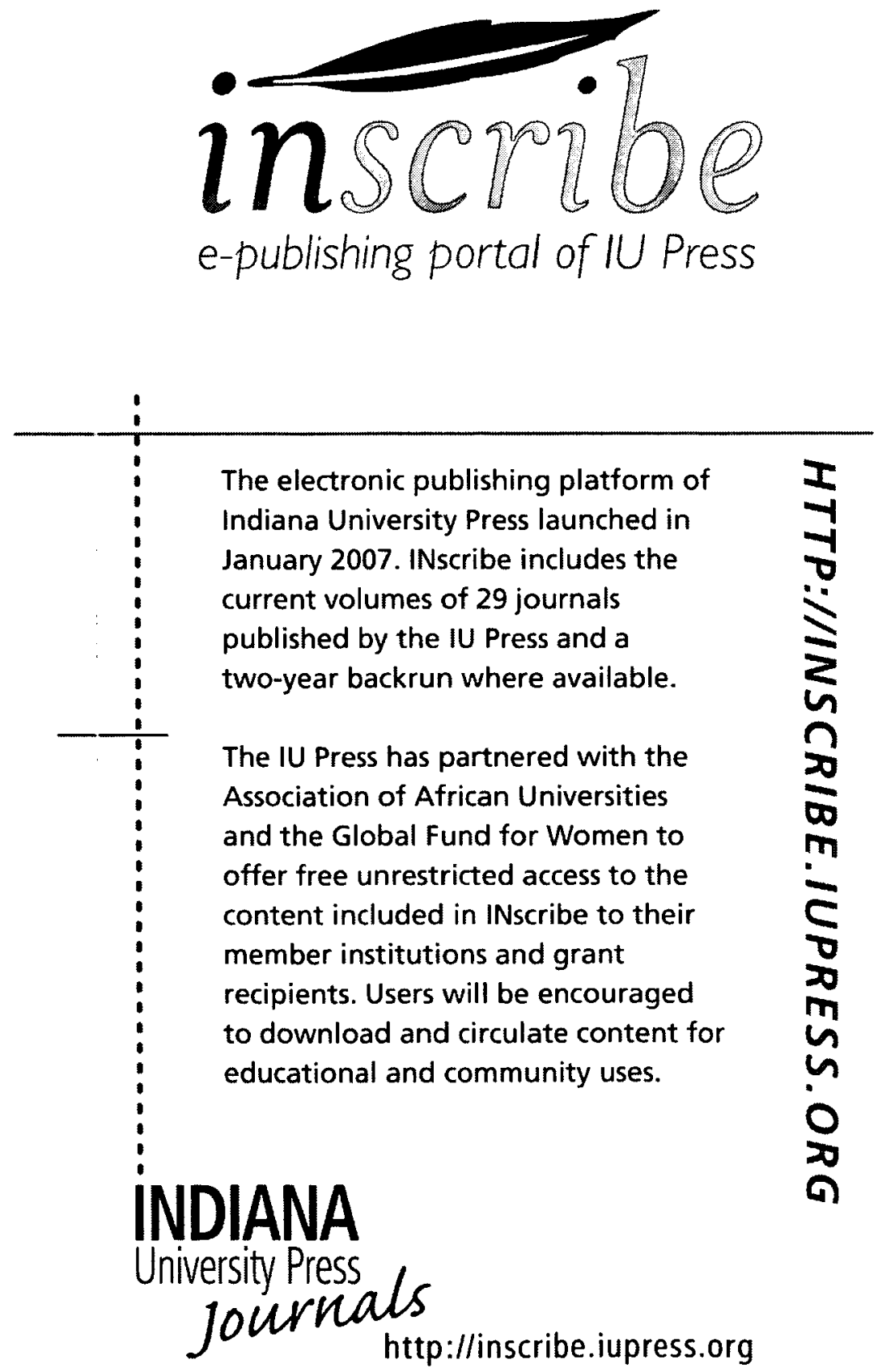